\title{
Stand up for the Burrup: Saving the Largest Aboriginal Rock Art Precinct in Australia
}

JENNY GREGORY

$\mathrm{T}$

he Dampier Archipelago is situated on the remote north-west coast of the Pilbara region of Western Australia (WA), 1600 kilometres from Perth. ${ }^{1}$ The region has a tropical, semi-desert climate with temperatures ranging from 0 to $45+$ degrees Celsius. Its economy is based on iron ore, gas and petroleum and in 2006 the export of Pilbara iron ore provided one-third of Australia's export revenue. It is at the heart of the state's current mining boom. ${ }^{2}$ The area known as the Dampier Rock Art Precinct is very large, covering a $45 \mathrm{~km}$ radius. It contains the 47 islands of the Dampier Archipelago and the Burrup Peninsula (formerly called Dampier Island). This is 


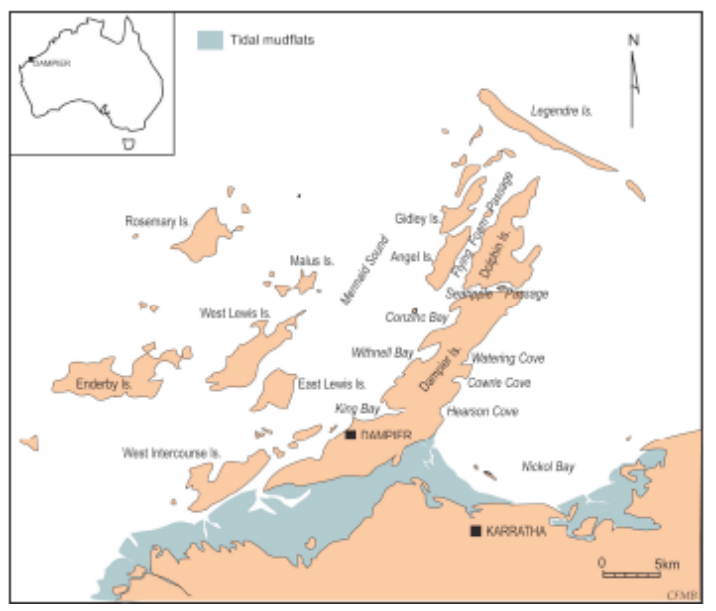

Figure 1: The Dampier Archipelago

Courtesy Bird and Hallam, 2006. Dampier Island is nowjoined to the mainland and is known as the Burrup Peninsula

the largest of the islands in the precinct at 117 square kilometres. It is here that rock art and industry are co-located.

In July 2007 the Federal Government announced that the Dampier Rock Art Precinct was to be listed on the Australian National Heritage list. The listing included much of the archipelago, but excluded the area leased by industry on the Burrup Peninsula. This article examines the complex background to this listing. Firstly, assuming that readers may not be familiar with the region or the rock art, and drawing on the work of archaeologists, the nature of the rock art in the area is outlined. Secondly, the troubled history of European-Aboriginal contact in the area is examined. Thirdly, the industrial development on the Burrup from the 1950s that continued the trajectory of indifference to Aboriginal people and their culture is discussed. Then follows an analysis of the gradual emergence of both environmental and heritage awareness in the area, and the difficult negotiations and confrontations that led to national heritage listing. Finally I query whether it should be assumed that the heritage campaign to save the rock art and the remarkable cultural landscape of the Dampier Rock Art Precinct is complete. 


\section{The Dampier Rock Art}

According to the documentation for the national heritage listing of 2007, the Dampier Rock Art Precinct contains one of the densest concentrations of petroglyphs (rock drawings) in Australia, with some sites having tens of thousands of images. ${ }^{3}$ More recent archaeological research, however, suggests that it may contain the largest concentration of rock art in the world. There are more than one million petroglyphs in the precinct with a minimum density estimated at more than one thousand motifs per square kilometre. Such a very high density is extremely rare. ${ }^{4}$

The petroglyphs are on the massive boulders and rocks that resulted from ancient weathering and erosion of pre-Cambrian volcanic lava flows that created the ridges and hills of the Dampier landscape. During the last Ice Age, some 50,000 years ago when Australia is thought to have been first settled and global climates were cooler than today, the polar ice caps were much larger and sea levels were up to $130 \mathrm{~m}$ lower. Then the Dampier Archipelago was a flat inland plain with a series of low rocky hills and ridges. Now the archipelago is a drowned landscape formed when the sea level rose at the end of the Ice Age. Throughout this period the area was used by small highly mobile bands of people who hunted in the area. Geological information and evidence from petroglyphs indicate that about 10,500 years ago there was a wide range of animals and birds in the area and then, as the sea level continued to rise and the Archipelago took on its present form about 6000 years ago, marine animals were increasingly used as a resource. ${ }^{5}$

Figure 2: Representations of extinct mammals: left, Thyalacine (Tasmanian tiger) and right, Fat-tailed Kangaroo
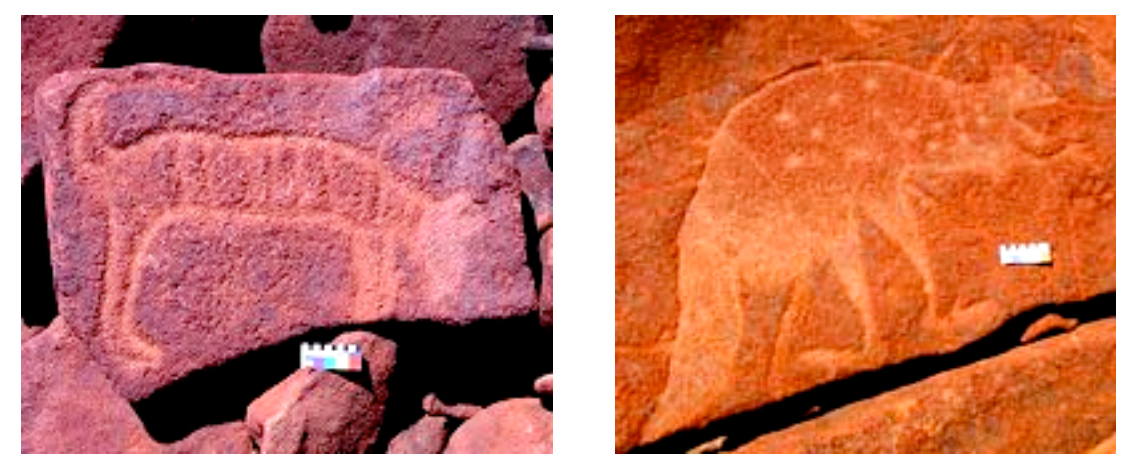
The rocks of the Dampier precinct are extremely hard and a number of different methods were used to create petroglyphs including pounding, abrading and scoring. Pecking, using both fine and coarse tools and a variety of techniques, was the most common. The Dampier rocks are well suited to this art form: when the dark weathered surface is removed the pale interior surface is revealed creating a sharp contrast, though over time this weathers and the contrast diminishes. Some petroglyphs are isolated, but some are in the thousands in rock galleries on boulder-strewn ridges and the sides of valleys where seasonal waterholes are located. Most of the petroglyphs are relatively small - less than $30 \mathrm{~cm}$ in size - but a few are as large as $150 \mathrm{~cm} .{ }^{6}$

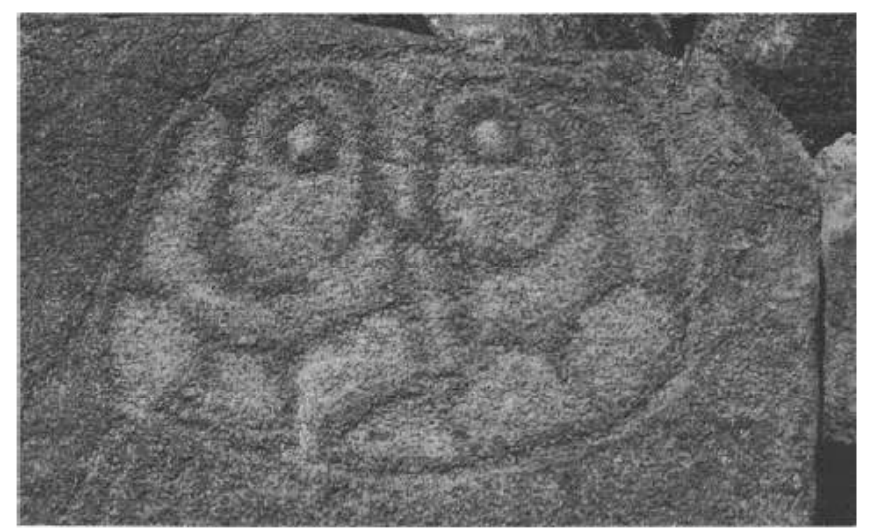

Figure 3: Archaic Face, Burrup Peninsula, Courtesy Ken Mulvaney

The Dampier petroglyphs are extraordinary in both their range and diversity. They include finely executed images of avian, marine and terrestrial fauna, as well as an exceptionally diverse and dynamic range of schematised human figures, some of which are part of complex scenes of human activity. The oldest petroglyphs are thought to be the deeply weathered 'archaic faces'. They provide an exceptional demonstration of the long and extraordinary history of extreme mobility, contact and shared visual narratives between Aboriginal societies on the Burrup and Central Australia because, as archaeologist Jo McDonald has demonstrated, these 'archaic faces' also exist in the gorges of the Calvert Ranges in the Western Desert 
and some $1500 \mathrm{~km}$ inland in sites such as the Cleland Hills in Central Australia. ${ }^{7}$

The dating of rock art is extremely difficult, but it has been estimated that the petroglyphs in the Dampier Rock Art Precinct range from 4000 to 30,000 years in age. In international terms the oldest of these petroglyphs are of remarkable antiquity. There are eighteen rock art sites that appear on UNESCO's world heritage list. Only one claims older rock art. The petroglyphs of the Gobustan Rock Art Cultural Landscape in Azerbaijan, added to the World Heritage List in 2007, are estimated to be up to 40,000 years old. In Europe the oldest world heritage rock art sites, with petroglyphs dated up to 25,000 years old, are in France's Vézere Valley where the Lascaux Cave is sited, and in Portugal's Coa River Valley. ${ }^{8}$

The Dampier Rock Art precinct also includes the largest and most diverse collection of stone arrangements in Australia. These include standing stones, stone pits, and complex circular stone arrangements, including lines of up to three or four hundred stones. Some of the standing stones were built to mark important resources, such as waterholes, soaks and camping areas. Others are thalu sites, where Aboriginal people held ceremonies to increase natural species or to bring rain. While on an international scale the Dampier standing stones are quite different from the most well known standing stones, like those at the world heritage sites of Stonehenge and Avebury in Britain erected between 3000 and 1600 BC, many are of far greater antiquity.

\section{European-Aboriginal Contact History}

In 1818, more than one hundred years after British sea captain and privateer, William Dampier, anchored in the archipelago that now bears his name, the archipelago was mapped by Captain Philip Parker King, who recorded the first known European contact with the indigenous inhabitants. But the area was not explored by Europeans until 1861, when Francis T. Gregory reported the existence of good pastoral country and opportunities for pearling. Pastoral settlement followed and the port of Tsien Tsin, renamed Cossack in 1872, was established near the mouth of the Harding River in $1863 .{ }^{9}$ The people of the Burrup at the time of early European contact were the Yaburara clan (also spelt Jaburara). They called the Burrup 'Murujuga', meaning 'Hip Bone Sticking Out'. Other groups in the 


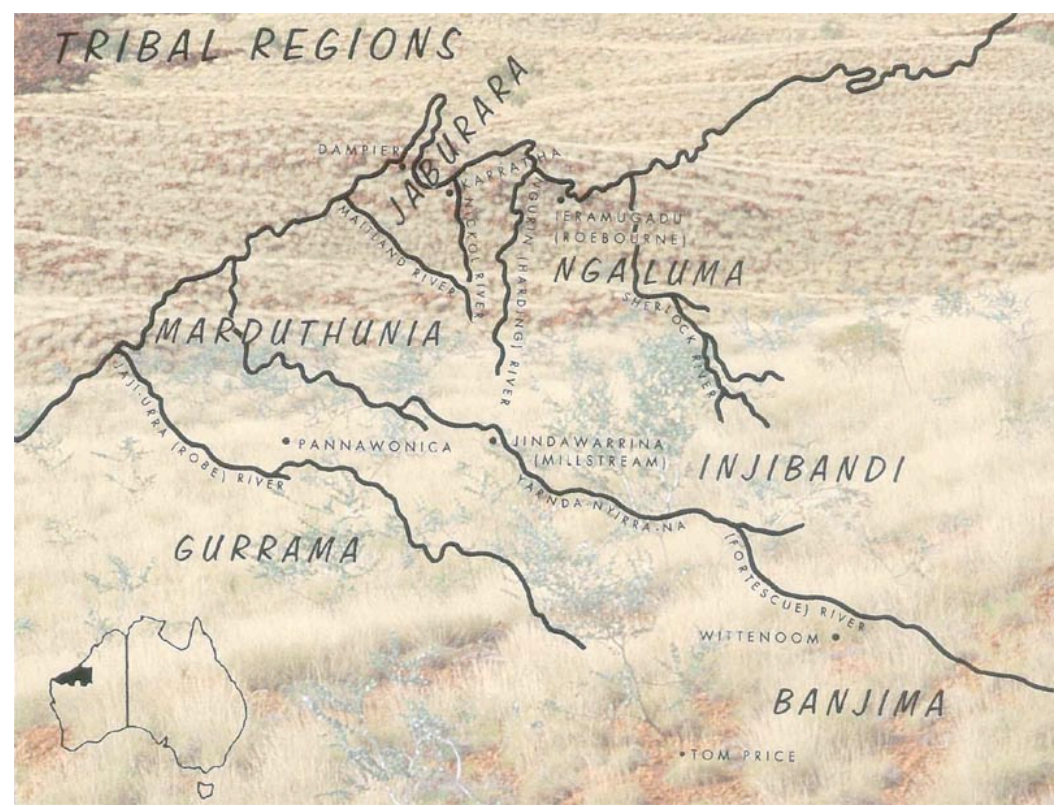

Figure 4: Map of Aboriginal tribal regions, courtesy of Ken Mulvaney. Note that the spelling of the names of these groups varies as there is no accepted standard spelling for Aboriginal words

adjacent region included the Ngalarma, the Mardudhenera and the Yindjibarndi.

To Europeans the land in the area seemed inhospitable - there are limited permanent water sources on the Burrup and the environment is very harsh in mid-summer. But Aborigines had subsisted and even thrived on the natural resources of the area, which they found in abundance. However, with the rapid development of the pastoral industry in adjacent areas the coastal tribes suffered from interference with both natural resources and their traditional patterns of life. They were alienated from their land, their water holes were fouled by cattle and sheep and their sacred sites were desecrated. Violent clashes resulted. The Ngarluma people were reduced to working as shepherds and labourers on pastoral stations in exchange for flour, tobacco and goods. There were also several smallpox epidemics that are thought to have reduced the Aboriginal population of the area by half. ${ }^{10}$

The Dampier Archipelago was used as a base for pearling for some thirty years. In the rush that followed the discovery of pearl 
shell, Cossack became the main port and by 1890 was one of the largest centres of pearling in the world. ${ }^{11}$ Initially shell could be gathered in shallow waters but, as these became depleted, Aboriginal men, women and children were coerced to dive for shells from pearling boats. As the industry grew there was a scarcity of labour and pearling masters recruited or kidnapped Aborigines (the latter known as 'blackbirding) from up to 600km away, taking them from their own country to work as divers in a foreign country. ${ }^{12} \mathrm{~A}$ small pearling base was established on Gidley Island, to the north-west of the Burrup Peninsula, and it was used as a 'prison' to hold Aboriginal labour. ${ }^{13}$

Nascent violence escalated after a European raped an Aboriginal woman in 1868. There are several versions of the event, which became known as the Flying Foam Massacre, as it was occurred near the Flying Foam Passage between Gidley Island and the Burrup Peninsula. It is clear that retribution was followed by punitive police action, that somewhere between twenty-six and sixty Yaburara people were shot, and that in a number of later attacks the remaining Yaburara people were driven from their homelands. ${ }^{14}$ Introduced diseases also claimed the lives of many Aborigines in the general area of the Dampier Archipelago. But many continued to work on pastoral stations and this enabled some to remain in their own country. However their social structure was further weakened when they and Aborigines from other areas were moved into a reserve at Roebourne in the 1940s, thus mixing peoples from a number of tribal groupings. ${ }^{15}$

During protracted Federal Australian Government Native Title hearings, concluded in 2003, no Aboriginal group was able to prove a continuing association with the area and claims for Native Title were rejected. The hearings had been complicated by competing and overlapping Native Title claims from three groups - the Ngarluma/Yindjibarndi, Yaburara/Mardudhunera and the WongGoo-Tt-Oo - for possession of the Burrup, as well as the involvement of powerful corporate and political groups. In early 2000 an investigative journalist, revealing an elaborate campaign to undermine native title in Western Australia and commenting specifically on the Burrup, summed up the situation in a television broadcast 'Secret White Men's Business': 
In Western Australia, there's a strange new chapter of an old story: a story of white people, black people and land. This time it involves big money, awkward bedfellows and communities pitted against one another. $^{16}$

This is not the palace for a detailed discussion of the complex negotiations and litigation. But it should be noted that Richard Bartlett, Professor of Law at the University of Western Australia, publically assessed the Native Title Act process as 'litigious, complex, bureaucratic, amazingly expensive and produc[ing] unjust results' ${ }^{17}$

During the hearings the State of WA negotiated a separate agreement with the Native Title claimants to acquire the Burrup land for industrial purposes. According to lawyer Frances Flanagan, the resulting 2002 Burrup and Maitland Industrial Estates (BMIE) Agreement is one of the most comprehensive agreements of its type. The BMIE Agreement extinguished Native Title claims over the industrial and residential areas of the Burrup Peninsula and other land required by the State of WA but granted claimants greater control over the non-industrial portions. ${ }^{18}$ From another perspective, it can be said to have enabled the WA State Government to acquire Native Title rights on the Burrup and adjacent land in return for the provision of economic benefits - education, training and a stake in future land developments - to the three Native Title claimant groups: the Ngarluma/Yindjibarndi, Wong-Goo-Tt-Oo and Yaburara/Mardudhunera peoples. According to a recent investigation the government tried

to smooth the way for heritage clearances by forcing the claimant groups into the controversial... agreement in exchange for $\$ 18$ million in royalties paid to the secretive Murujuga Corporation. ${ }^{19}$

The politics of engagement between the various Aboriginal groups in the area are complex. Aboriginal people still retain cultural association with the Burrup. But according to one view, the government allowed small family groups, representing only about fifty people, to take the majority of places on the Murujuga Corporation's governing body, thus giving them greater representation than the Ngarluma and Yindbarndi groups which 
represent some 900 people. The Ngarluma Aboriginal Corporation believes that the Murujuga Corporation has also given the green-light for 'the continued desecration of their heritage on the Burrup' ${ }^{20}$

\section{Industry and the Dampier Archipelago}

The industrial history of the Dampier Archipelago began in the 1950s. The first offshore gas deposit on the North West Shelf was discovered in 1954 and in 1962 there was a proposal to establish a deep water port on Depuch Island (now Dolphin Island) in the Archipelago. However, as a result of an impact study by the WA Museum that identified the island's exceptional Aboriginal heritage - 'in its context as one of the most remarkable native art sites in existence' - the port plan was abandoned, temporarily. ${ }^{21}$ Increasing mineral exploration in the Pilbara and the identification of iron ore reserves inland led to an agreement between the State Government and Hamersley Iron to develop a port at the newly created town of Dampier (gazetted in 1969).

The nearby town of Karratha (the Regional Centre with a population of 11,728 in 2006) was gazetted in 1972 as a result of the continued development of the Hamersley iron project and the establishment of the Dampier Salt project, which had commenced feasibility studies in the area in 1967. Its first shipment was sent to Japan in 1972 and in the following year, with the permission of local Aboriginal elders, the Chairman of Dampier Salt presented a petroglyph with a carving of a turtle to the Tokyo Museum on behalf of the WA Museum. ${ }^{22}$ As a result of the Dampier Salt project, Dampier Island was linked by a causeway to the mainland and renamed Burrup Peninsula in 1979. ${ }^{23}$ Dampier Salt, now a member of the Rio Tinto group, is the world's largest exporter of reliable, high quality bulk solar salt in $2008 .^{24}$

Following the discovery of further offshore gas reserves, the Burrup Peninsula was chosen as the site for a gas plant. Woodside had acquired exploration permits on the North West Shelf in 1963 and selected two possible locations for the gas plant in 1969. After an environmental assessment and a report by the Registrar of Aboriginal Sites at the WA Museum recommended the Withnell and King Bays area on the west coast of the Burrup as the preferred site, Woodside's planning proceeded. The State Department of Industrial Development commissioned an engineering report on port and land use planning on the Burrup, which concluded that there was no 
serious conflict between industrial development and conservation requirements. A further report from the WA Museum, however, identified the archipelago as a major archaeological resource, specified that consultation with the Aboriginal people was essential, and proposed a comprehensive site survey. This did not occur. The WA State Government adopted the engineering report, zoning the Withnell and King Bays area for industrial development. ${ }^{25}$

In 1980 the giant North West Shelf Joint Venture (NWSV) was formed to pursue offshore petroleum and gas opportunities. The consortium now comprises BHP Billiton Petroleum Pty Ltd, BP Developments Australia Ltd, Chevron Australia Pty Ltd, Japan Australia LNG (MIMI) Pty Ltd, Shell Development (Australia) Ltd, and Woodside Petroleum Ltd, each holding equal one-sixth shares of gas sales. The NWSV Karratha Gas Plant, located on the Burrup Peninsula, was completed in 1984 and is managed and operated by Woodside (see Figure 6). It is Australia's largest resource development project, with investments of more than AU $\$ 15$ billion since its establishment. It supplies natural gas to WA's domestic market, liquified natural gas (LNG) to Japan and condensate, crude oil and liquified petroleum gas to other international markets. ${ }^{26}$ With further gas discoveries and increasing markets, Woodside unveiled a plan for an expansion of the NWSV facilities on the Burrup Peninsula in 1995. Expansion was rapid: in 1995 a milestone 500th cargo of LNG was shipped to Japan, only four years later the 1000th LNG cargo had been shipped out. ${ }^{27}$

Throughout this period the WA State Government provided considerable encouragement to industry to further develop the Burrup. ${ }^{28}$ More LNG trains (used to process gas) were built at the NWSV gas plant, the Federal Government injected \$35.4 million for the development of common-use infrastructure on the Burrup in 2003, a new LNG carrier was delivered for the Dampier-Japan service, and a second offshore gas pipeline was commissioned in 2004. That year the NWSV celebrated fifteen years of LNG production at its Burrup processing facilities and the following year its initial contract with the WA State Government to supply gas to the State was renegotiated to run to 2020. The WA Premier opened Oswald of India's ammonia plant on the Burrup in 2006. ${ }^{29}$ 


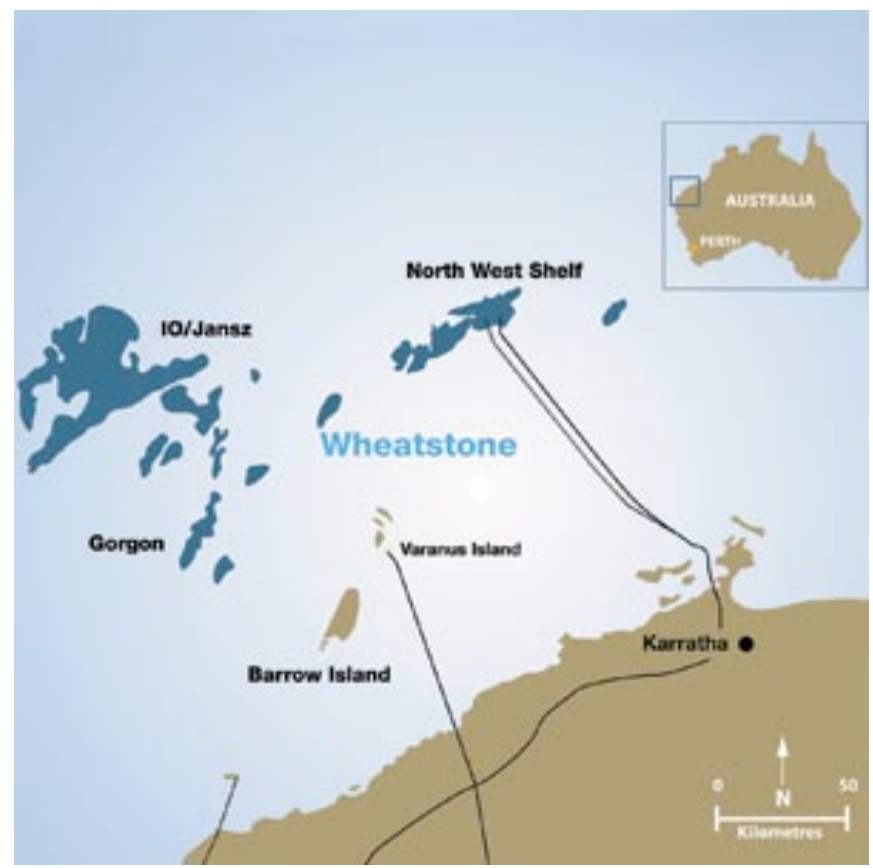

Figure 5: Liquid Natural Gas Projects off the Dampier Archipelago(nr Karratha). The Pluto Gas Field is located to the south-eastof the IO/Jansz Field (March 2008)

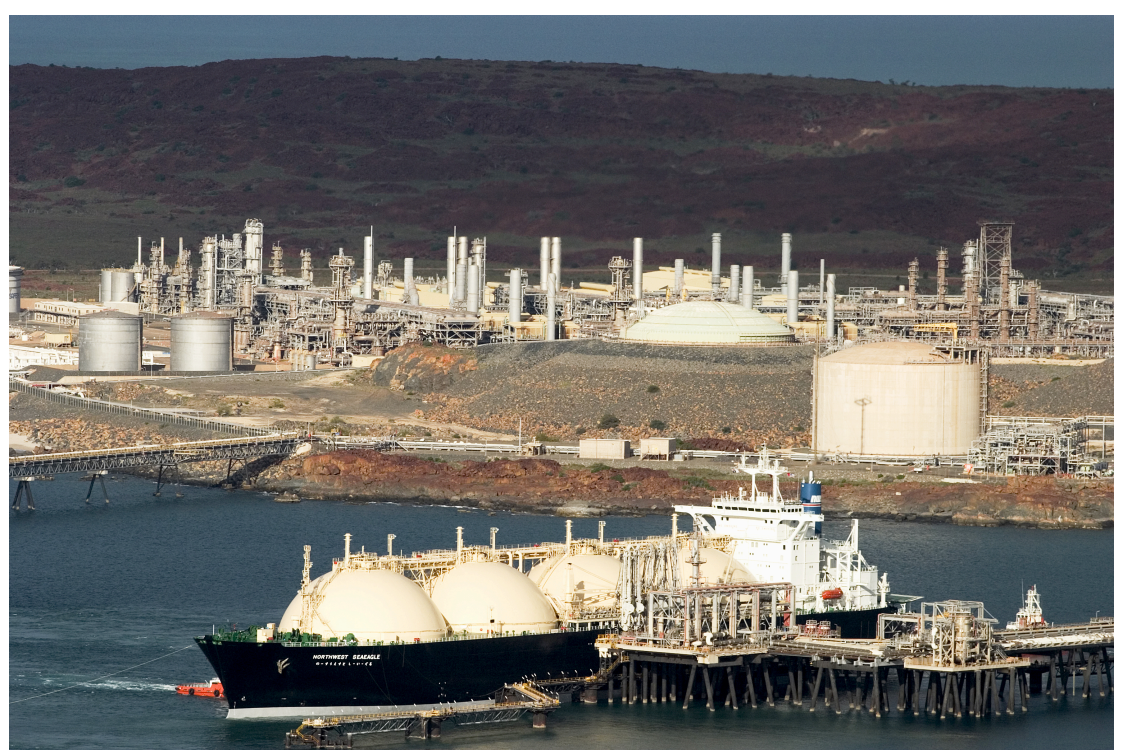

Figure 6: Karratha Gas Plant, North West Shelf Venture on the Burrup Peninsula (Courtesy Woodside Energy Ltd) 
Throughout this period Woodside Energy, manager and operator of the NWSV gas plant was working on plans to build its own gas processing plant on the Burrup following its discovery of the Pluto gas field. Woodside began site construction work in January 2007, a month before the WA State Government granted permission for them to begin land clearing. ${ }^{30}$ This included moving 165 petroglyphs.. The Environmental Protection Authority (EPA) did not give Woodside the approval to build the Pluto LNG processing plant on the Burrup until August 2007. ${ }^{31}$ A further six months on, the Federal Government also gave approval, thus giving Woodside the formal go-ahead from both tiers of government for its plans to develop the $\$ 12$ billion Pluto gas field and to construct associated LNG facilities on the Burrup. ${ }^{32}$

Although the WA State Government had refused, and still refuses, to list the Burrup on the State Heritage List, the WA State Treasurer released a media statement in June 2007, welcoming the Federal Minister for the Environment's imminent announcement that the Dampier Rock Art Precinct was to be placed on the National Heritage List stating that 'the Government has long supported the significant heritage values of the Dampier Archipelago'. His comment that 'these have been recognised in the various planning strategies prepared by the State over the past decade' was a remarkable demonstration of political spin, leaving heritage advocates open-mouthed. ${ }^{33}$

The environmental approvals granted by state and federal governments had come with conditions. Hence in October 2007 Woodside signed a $\$ 100$ million deal with the CO2 Group for the planting of mallee trees in NSW and WA to offset carbon emissions from its Pluto LNG project. As a result of these developments, in November 2007, the NWSV abandoned its planned extension of domestic gas production at its Burrup plant. Although the NWSV determined not to increase the size of the original plant, in March 2008, a member of the consortium, US energy giant Chevron, announced a $\$ 10$ billion project to develop its massive gasfield, Wheatstone, $145 \mathrm{~km}$ north-west of Karratha via a pipeline to the Pilbara coast (see Figure 5). The project is similar in size to Woodside's Pluto project, but there is no indication of the likely position of the plant or whether it will impact on the Dampier Rock Art Precinct. $^{34}$ 
And the future? The numbers are huge, whether it be shipping cargoes, quantity of gas or dollars. The stakes are high. The timing of approvals suggests that industry may have wagged the tail of government.

\section{The Environment and the Dampier Archipelago}

What of the environmental story of the Dampier Rock Art Precinct? In 1967 naturalist Harry Butler was appointed conservation consultant to WA Petroleum (WAPET) in an early industry move to protect the environment. He was a household name through his nationally broadcast television program In the Wild with Harry Butler, in which Australia's favourite naturalist was noted for picking up rocks and marvelling at the wildlife thus revealed. In 1981 Butler featured in a film about the Burrup produced for television. He was then employed as an environmental consultant for the North West Shelf natural gas project. His job was to monitor the effect of the development on the peninsula and its wildlife. He also wrote a sixteen-page booklet Do Your bit for Burrup: Help Protect the Native Plants, Wildife and Aboriginal Heritage of the Burrup Peninsula, published by Woodside to show what Woodside was doing to protect the environment. ${ }^{35}$ There has been a mixed reaction to Butler's decision to work with industry and teach them about conservation. Some respect his position, others condemn it: 'Harry Butler sold out to major companies long ago', say some. ${ }^{36}$

In the end companies are responsible to their shareholders to maximise profits and financial considerations must be uppermost. It was only with the Environmental Protection Act, proclaimed in 1971, that government legislation began to protect the environment, though even then loopholes in the legislation and pressures on the regulating authority have resulted in less than ideal results.

Apart from concerns about the impact of industrial development and increasing visitor impact on the petroglyphs, there was also anxiety about the impact of industrial air pollution on the petroglyphs. Hence in 2002 the WA State Government established the Burrup Rock Art Monitoring Committee as part of its BMIE Agreement with the Native Title claimants. An independent report by Australia's Commonwealth Scientific and Industrial Research Organisation (CSIRO) indicated that 'Burrup Peninsula air pollution concentrations were very low in industrial areas and similar to those found throughout the Pilbara'. ${ }^{37}$ 


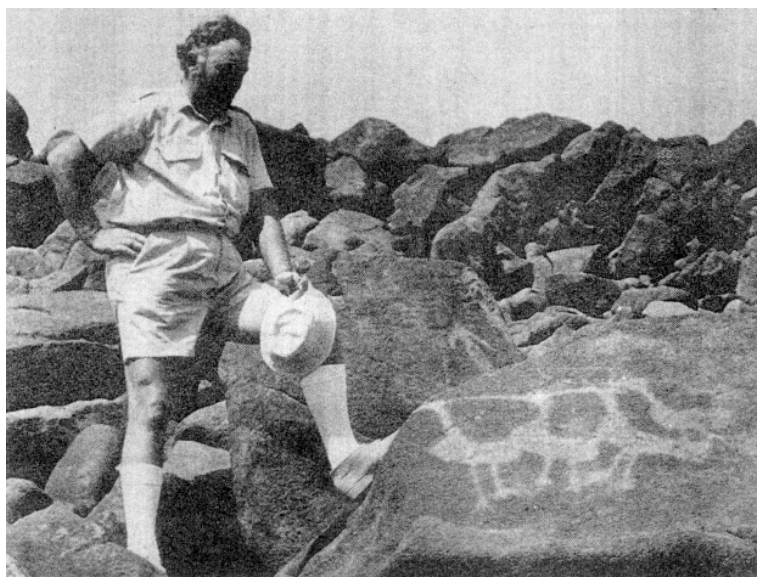

Figure 7: Enzo Virili alongside a petroglyph, 8 February 1973, courtesy Hamersley News

\section{Heritage Advocacy}

The story of heritage interest in the rock art of the Dampier Archipelago began in the late 1960s. Robert Bednarik, President of the International Federation of Rock Art Associations between 2000-4, was then working for a mining company in Dampier and began to record hundreds of sites on Dampier Island (later the Burrup). ${ }^{38} \mathrm{He}$ was followed by Enzo Virili, an engineer employed on the Dampier Salt project in the early 1970s, who also recorded rock art - mapping, cataloguing and photographing over 6000 individual petroglyphs in an area of approximately five square miles on Dampier Island and later giving a paper on his work to the Australian Institute of Aboriginal Studies in Canberra. ${ }^{39}$

Following the passage of the WA Aboriginal Heritage Act in 1972, official recording began by staff of the WA Museum, notably Kingsley Palmer. ${ }^{40}$ However, despite the passage of the act and later amendments, there has been considerable criticism of its impact. Former Yamatji Land and Sea Council principal legal officer David Ritter, for example, has argued that:

It is a myth, expressed by the objects of the Aboriginal Heritage Act that the main purpose of the legislation is to protect Aboriginal heritage. It may be more accurate to describe the AHA as an act to regularize the obliteration of Aboriginal heritage... It is legislation by the non- 
Indigenous community for the non-Indigenous community that creates a superficial veneer of protection for Indigenous interests. The result is that the colonizing power can continue to do with Aboriginal places and materials exactly as it wants. ${ }^{41}$

When the development of the NWSV's gas field began, Woodside was required to negotiate the choice of a site for the NWSV gas plant with the Department of Aboriginal Sites (DAS) at the WA Museum. Of Woodside's two preferred sites, DAS chose the Withnell and King Bays area because at that time it was thought that development there would have the least impact on Aboriginal heritage sites. Few Aboriginal people were consulted during the process. In assessing the environmental impact on the site, the EPA recommended that Woodside employ an archaeologist and underlined the need for a comprehensive survey of the archipelago. ${ }^{42}$

The result was the first survey of a handful of surveys in the Dampier Archipelago. Woodside engaged the WA Museum to survey and record rock art and other archaeological material affected by the construction of the NWSV gas plant on the Burrup. The survey took place over a sixteen-month period beginning in 1980 and covered fifteen per cent of the peninsula. However although 720 petroglyph sites were recorded, the result was that only 315 were preserved in situ. Woodside relocated the rest of the petroglyphs to a fenced compound. A full analytical report of the survey was never completed. In the early 1990s the Department of Conservation and Land Management conducted a second survey, covering an area of about eight per cent of the Burrup Peninsula and recording 498 sites. Several other small archaeological surveys have been undertaken, but the surveys to date have covered only a small fraction of the Dampier Archipelago, have been based on different briefs, and have been of variable quality. In 2005, as part of the assessment of the site for national heritage listing, a report on the heritage of the Dampier Archipelago, via a desktop study reviewing existing studies highlighted the outstanding significance of the rock art, concluded that the entire area should be regarded as a continuous archaeological landscape. ${ }^{43}$

For many years archaeologists such as Pat Vinnicombe and Ken Mulvaney and others had fought, without success, to protect the rock art of the Dampier Archipelago that, as far as industry and most 
relevant government departments were concerned, could be relocated. ${ }^{44}$ With escalating industrial pressure, the WA Greens and the National Trust of Australia (WA) became increasingly concerned. In 2002, the Trust and the Hon Robin Chapple MLC nominated the Burrup Peninsula to the Australian Council of National Trusts' Australian Endangered Places list. ${ }^{45}$ In a precursor to the groundswell of protest that would develop across the world, about 600 people, including representatives from Roebourne Shire, the Greens, One Nation and the Wong-Goo-Tt-Oo marched on the Burrup Peninsula and met with the WA State Development Minister to protest against the WA State Government's endorsement of development and to propose that the Burrup works be moved to the Maitland industrial area, south-west of Karratha that was already zoned for heavy industry. ${ }^{46}$ Following lobbying from the National Trust (WA), the precinct was placed on the World Monument Fund's list of endangered places in 2004. It is the only Australian site to have appeared on that list.

The National Trust called for a full study of the area and the development of a management plan believing that a win-win solution that saved the rock art for the world and did not disadvantage industry was feasible. Financial support from the World Monument Fund had made an education campaign possible with the first of the National Trust's forums held in Perth in July 2003. At that forum, in a surprise turnaround, Colin Barnett, Minister for Industrial Development in a former Liberal State Government (and since September 2008 Premier of the State) came out in favour of protecting the rock art of the Burrup. ${ }^{47}$ In 2004 a group comprising the National Trust, native title claimants and Bednarik, President of the International Federation of Rock Art Organisations, nominated the Dampier Rock Art Precinct to the Australian Heritage Council for national heritage listing. As a result in the following year the Commonwealth Department of Environment and Heritage commissioned a report on the significance of the rock art. Throughout 2006 the Trust held seminars in the major Australian capital cities as well as Karratha where locals were heartened by the extent of support. Political lobbying won the support of the Federal Opposition Labor Party and the Greens in Federal Parliament. ${ }^{48}$

However, things were not rosy at the State level. The Heritage Council of WA was initially reluctant to consider the Dampier Rock 
Art Precinct for State Heritage listing, arguing that Aboriginal heritage lay outside the scope of the Heritage Act of WA. Legal advice showed that this view was incorrect and in July 2006 the Heritage Council toured the area by four-wheel drive to the southern part of the Burrup and by boat through the waters of the archipelago. The Council also attended a National Trust seminar in Karratha. At the same time two Federal Senators from the Green Party toured the area using a helicopter to visit the more inaccessible northern section of the Burrup Peninsula. Detailed consideration of the heritage values of the area by the Heritage Council of WA soon followed but their recommendation that the area be listed on the State Heritage List was rejected by the Minister for Heritage. This decision must be seen in the context of the politics of State Cabinet, the strength and influence of the mining lobby in the bureaucracy, the political and the corporate sector and a state economy in the grip of once-in-a-lifetime mineral boom..$^{49}$ However, in September 2006 the Australian Heritage Commission's assessment was completed and it recommended that the Dampier Rock Art Precinct be listed on the Australia's National Heritage List. ${ }^{50}$ Despite this Woodside was given environmental approval by the WA State Government to go ahead with its new Pluto plant though, following intense pressure, the company dropped its opposition to the listing of rock art.

Community activism played an important role in gaining national listing of the Dampier Rock Art Precinct. Individuals in the region, both Aboriginal and European, and the Greens WA played a vital role in drawing attention to the plight of the rock art and the cause was taken up by the National Trust, Australia's pre-eminent community heritage organisation, to advocate for the protection of the rock art. They were joined by several new groups. Champions of the Burrup Rock Art (COBRA) was formed in Karratha and, in November 2006, the Friends of the Pilbara Rock Art (FARA) - a loose coalition of concerned people including Aboriginal people, academics, artists, lawyers, and others - was formed to develop strategies to save the rock art. Its major contribution has been to raise awareness of the issue around the globe. One strategy was to organise 'Stand Ups'. FARA asked people around the world to literally stand up at places of cultural significance in their country, wearing T-shirts spelling out the slogan 'Stand Up For The Burrup'. By October 2008 FARA had organised 85 Stand Ups in Australia and 101 international Stand Ups. During this period GetUp, an on-line 


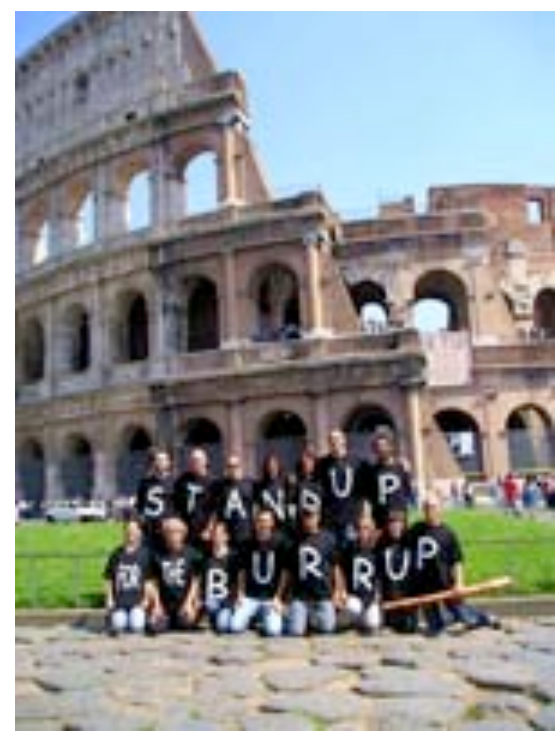

Figure 8: Stand Up in Rome, 19 April 2007, courtesy Friends of Australian Rock Art

community group dedicated to taking innovative and effective action on important issues facing Australia, also became involved, organising a petition with over 42,000 signatures, presented at Woodside's Annual General Meeting in 2007, and calling for an alternative location to process the offshore gas. ${ }^{51}$

During a tense period - December 2006 to February 2007 - the Federal Minister for Environment and Heritage used delaying tactics to put off a final decision. There was an attempt to force amendments to the relevant legislation through the Federal Parliament, the sacking of the responsible Federal minister, the appointment of a new minister and further delays. The issue was handballed back to the WA State Government, where the Hon Michelle Roberts, who held the portfolios of both Aboriginal Affairs and Heritage and who had previously rejected state listing of the precinct, gave approval for work to commence on Pluto Site B stating:

The importance of the Woodside project goes beyond its importance to the state of Western Australia, it extends to the national economy... This decision is important to the state of Western Australia and in today's dollar terms 
will generate $\$ 17.5$ billion to the national economy... [and] \$28 billion in wealth to the state economy. ${ }^{52}$

Work had already begun on the site..$^{53}$

At the Federal level the momentum for national heritage listing continued. Dialogue had begun between the National Trust (WA) and the officials of the Federal Department of Environment to work towards finalisation of the boundaries of a national listing and to determine the broad content of the Bilateral Agreement between State and Commonwealth that would underpin statutory protection.

After months of anticipation, on 3 July 2007 the Federal Minister for Heritage announced that the Dampier Rock Art Precinct was to be placed on National Heritage List, noting 'Cooperation between indigenous communities, the WA Government, and companies including the North West Shelf Venture, Rio Tinto, Woodside Energy and other stakeholders including the National Trust of WA' ${ }^{\prime 4}$ This 'co-operation' meant that some areas had been excised. Although 99 per cent of area on which national heritage values occur had been included in the listing, the one percent that had not been included covered the NWGSV's Karratha plant, Woodside's Pluto leases and the Burrup Fertilizer site. Hence the response from activists was not what governments might have hoped. A rally on the future for the Burrup was held outside Parliament House, Perth, on 13 July 2007, with a weekend of international protest in the USA, France and Italy. National listing had no affect on the relocation of the petroglyphs.

\section{The Future}

What is the future for the Dampier Rock Art Precinct? How will the Archipelago and its precious rock art be managed and interpreted? Who will take responsibility - the Commonwealth or the State? Is an Aboriginal-European partnership possible?

The situation is unclear. The bilateral agreement between Commonwealth and State, necessary under federal legislation to ensure adequate protection and management, has not yet been completed and there appears to be a stalemate between governments. Yet work is apparently proceeding within the State Departments of Environment and Conservation, and Industry and Resources in consultation with Indigenous communities via the Department of Indigenous Affairs to develop initiatives 'to protect the outstanding national heritage values of the area'. Native title has been 
extinguished, but under the BMIE Agreement 62 per cent (4900ha) of the Burrup Peninsula was set aside for transfer to the Murujuga Aboriginal Corporation and management as a conservation reserve in exchange for unrestricted access to existing industrial zones and their expansion to the West Intercourse Island and the Maitland area south of Dampier. This, however, has been complicated by the announcement of a restructure of the Department of Indigenous Affairs and it appears that the Department of Industry and Resources has become the lead agency. ${ }^{55}$ In a more recent twist, with the election of a new state government in September 2008, future developments at the state level became unclear. But with a Premier who came out in favour of protecting the Burrup when in opposition, despite his previous life as a Minister for Industrial Development, the situation looks hopeful.

In a parallel development, as a requirement of national heritage listing, Woodside has entered into an agreement with the Federal Government. The agreement includes a commitment by Woodside to invest up to \$34 million through a Rock Art Foundation dedicated to identifying, managing and promoting the natural heritage values of the Dampier Rock Art Precinct. ${ }^{56}$

Meanwhile FARA's Stand Up protests continue throughout the world.and at the end of 2009 they numbered 219. Recognising the power and importance of industry, FARA realises that national heritage listing is a milestone, rather than completion of the journey, in the process towards protection.

\section{Conclusion}

This article has reflected on the many years of complex struggle to safeguard the ancient rock art of the Dampier Archipelago through national heritage listing. It has examined the nature of the rock art and briefly traced a history of European-Aboriginal contact in the area. Ironically it was the beginnings of industrial development on the Burrup from the 1950s that led to wider knowledge of the rock art and then the struggle to gain recognition of its heritage significance, which eventually led to the national heritage listing of the Dampier Rock Art Precinct. The precinct is clearly of immense significance as a cultural heritage landscape.

Why then has recognition of its importance been such a struggle? The Dampier Rock Art Precinct is remote, lying in one of the most 
isolated corners of the globe. It is immense - many find it difficult to conceive of the area as one vast cultural landscape. It holds cultural treasures but is adjacent to the earth's mineral riches. The value of its ancient petroglyphs cannot be measured. Its offshore gas resources are of immediate and immense financial value. With the advance of industry it was inevitable that there would be a clash. But complicating this further were the politics of heritage. If this was a site of European heritage significance rather than Aboriginal heritage significance it is difficult to imagine that recognition would have been so difficult to achieve. The destruction of Aboriginal rock art to meet the needs of industry is an example of continuing indifference to Aboriginal culture. Furthermore the situation has been complicated by the fact that Aboriginal groups in the area have been significantly impacted by a tragic history of European-Aboriginal relations. Yet while most Yabararu people were wiped in the 1868 massacre, descendants and neighbouring groups maintain custodial responsibilities for the area.

As Andrea Witcomb and Kate Gregory have recently argued, the Burrup has now become a 'contact zone' of ethical responsibility for both Aboriginal and settler peoples that goes beyond its archaeological significance alone. Its heritage has become the heritage of all Australians and thus provides 'a means to foster a practical form of reconciliation' ${ }^{57}$ Much remains to be done before there is certainty that the rock art of the Burrup has been saved but significant steps have been taken. It should be remembered, however, that out on the Burrup the politics of the past is no trivial academic game.

\section{Endnotes}

${ }^{1}$ An earlier version of this paper, 'Relocating Rocks: the battle to save the largest Aboriginal rock art precinct in Australia', was presented at the Heritage 2008 conference. See R. Amoeda et al, World Heritage and Sustainable Development: Heritage 2008 International Conference, Greenlines Institute for Sustainable Development, Barcelos, Portugal, 2008.

${ }^{2}$ William Walker, 'Pilbara', in Jenny Gregory and Jan Gothard (eds), Historical Encyclopedia of Western Australia, UWA Press, Crawley, 2009, pp691-93.

${ }^{3}$ Australian Heritage Database, Dampier Archipelago (including Burrup Peninsula), Place ID 105727, Listed Place (03/07/ 2007), http://www.environment.gov.au/cgi- 
bin/ahdb/search.pl?mode=place_detail;place $i d=105727$, accessed 12 December 2009.

${ }^{4}$ Drs Alistair Paterson and Liam Brady, personal communication regarding the most recent archaeological surveys in the Dampier Rock Art Precinct, November 2009.

${ }^{5}$ Caroline Bird and Sylvia J. Hallam, 'A Review of archaeology and rock art in the Dampier Archipelago', a report prepared for the National Trust of Australia (WA), 2006.

${ }^{6}$ ibid; Pat Vinnicombe, 'Petroglyphs of the Dampier Archipelago: background to development and descriptive analysis', Rock Art Research, vol 19, 2002, pp3-27.

${ }^{7}$ Jo McDonald, 'Archaic Faces to Headdresses: The Changing Role of Rock Art across the Arid Zone' in P. Veth, M. Smith and P. Hiscock (eds), Desert Peoples: archaeological perspectives, Blackwell, Oxford, 2005, pp116-41.

${ }^{8}$ UNESCO World Heritage List, nd (Online). Available: http:// whc.unesco.org/en/list. (Accessed 14 August 2009).

${ }^{9}$ Kay Forrest, The challenge and the chance: the colonisation and settlement of north west Australia 1861-1914, Hesperian Press, Carlisle, WA, 1966.

${ }^{10}$ Daniel v State of Western Australia, FCA 666 (Online), 3 July 2003, Federal Court of Australia, Available: http://www.austlii.edu.au/cgibin/sinodisp/au/cases/cth/federal ct/2003/666.html?query=title(Daniel $\% 20 \%$ 20and $\% 20 \%$ 20Western \%20Australia\%20, accessed 14 August 2009.

${ }^{11}$ S. Kwaymullina, 'For marbles: Aboriginal People in the Early Pearling Industry of the North-West' in J. Milroy, J. Host and C.T. Stannage (eds), Wordal: Studies in WA History, no 22, 2001; A.C.V. Bligh, The Golden Quest, Hesperian Press, Carlisle, WA, 1958; K. De La Rue, Pearl Shell and Pastures: the Story of Cossack and Roebourne, and their Place in the History of the North West, from the Earliest Explorations, Cossack, WA, 1984; Cossack Project Committee (Inc.), Cossack, WA, 1979; Karratha Community Library, Local History Collection (Online), No longer available: http:/ / www.roebourne.wa.gov.au/historyaboriginal.htm accessed January 2008.

${ }^{12}$ Kwayllumina, 'For marbles', op cit; Brian Shepherd, 'Pearling', in Gregory and Gothard, Historical Encyclopedia, pp668-71; Blaze Kwaymullina, 'Blackbirding' in Gregory and Gothard, Historical Encyclopedia, pp132-33.

${ }^{13}$ Author, pers comm, 2006.

${ }^{14}$ Shepherd, op cit; Trevor Solomon, 'Massacre, Flying Foam' in Gregory and Gothard (eds), Historical Encyclopedia, p559.

${ }^{15}$ Daniel v State, op cit.

${ }^{16}$ Stephen McDonell, 20 March 2000, 'Secret White Men's Business', Four Corners, ABC (Online). Available:

http://www.abc.net.au/4corners/stories/s111958.htm accessed 14 August 2008.

${ }^{17}$ Richard Bartlett, 'The Denial of Native Title to the Resources of the Burrup Peninsula and the Pilbara: Daniel v State Western Australia', Australian Resources and Energy law Journal, vol 22, no 4, 2003.

${ }^{18}$ Frances Flanagan, 'The Burrup Agreement: a case study in future act negotiation', atns agreements, treaties and negotiated settlements project, nd (Online). www.atns.net.au/papers/Flanagan\%20Paper.pdf accessed 14 August 2009. 
${ }^{19}$ Armstrong, 'Native title no gift for Roebourne', West Australian, 8 March 2008.

${ }^{20}$ ibid.

${ }^{21}$ E.H.M. Lewis, Minister for Education and Native Welfare, Press release, 23 December 1964.

${ }^{22}$ Hamersley News, 25 January 1973.

${ }^{23}$ 'Burrup' is not an Aboriginal word. The Peninsula is named after Mt Burrup, the highest hill on the then Dampier Island. In 1885 the Government Surveyor named Mt Burrup after Henry Thomas Wood Burrup, a young accountant, who had been murdered on the Union Bank premises at Roebourne earlier that year.

${ }^{24}$ Dampier Salt, nd (Online), Available: http:/ / www.dampiersalt.com.au accessed 14 August 2009.

${ }^{25}$ B. J. Wright, Rock art of the Pilbara region, North-west Australia, Australian Institute of Aboriginal Studies, Canberra, 1968; Bird and Hallam, op cit.

${ }^{26}$ NWSG, n.d. (Online), Available: http:/ / www.woodside.com.au/Our+Business/Production/Australia/No rth+West+Shelf/, accessed 14 August 2009.

${ }^{27}$ Woodside, nd (Online),'Timeline: 50 Years of Woodside's Energy', Available: http://www.woodside.com.au/About+Us/Profile/History.htm accessed 14 August 2009.

${ }^{28}$ Fertilizer Focus, 'Burrup Fertilisers ammonia plant officially opened', May / June 2006.

${ }^{29}$ Drummond, 'The $\$ 70$ million Taj on the Swan', West Australian, 8 September 2007.

${ }^{30}$ WA Business News, ‘Woodside's Pluto Development wins Federal Approval', 12 October 2007.

${ }^{31}$ Andrew Burrell, 'Pluto gets conditional go-ahead', Australian Financial Review, 25 August 2007.

${ }^{32}$ WA Business News, op cit.

${ }^{33}$ Hon Eric Ripper, 'State Government backs heritage values of Dampier Archipelago', Media Statement, 21 June 2007.

${ }^{34}$ West Australian, 10 March 2008.

${ }^{35}$ Harry Butler, Do Your bit for Burrup: Help Protect the Native Plants, Wildlife and Aboriginal Heritage of the Burrup Peninsula, Woodside Offshore Petroleum, Karratha, WA, 1989.

36 ‘The Dampier Archipelago - LETS SAVE IT! (Online), 2008, Message board, comment posted by peaceleo69, 18 February 2008, No longer available: http:/ / au.messages.yahoo.com/news/nationalnews / 50745? p=last accessed March 2008.

${ }^{37}$ Hon John Bowler, 'First scientific report on Burrup air quality', Media statement, 16 October 2006; Burrup Rock Art Monitoring Management Committee (Online), August 2007 Update (PDF), Available:

http:/ / www.dmp.wa.gov.au/4858.aspx\#4860 accessed 14 August 2009.

${ }^{38}$ For Bednarik's continuing involvement see R.G. Bednarik, 'Dampier rainwater as acidic as beer', Rock Art Research, vol 24, no 1, 2007; R.G. Bednarik, Australian Apocalypse: the story of Australian greatest cultural monument, Australian Rock Art Research Association, Melbourne, 2006; and R.G. Bednarik, 'The survival of the Murujuga (Burrup) petroglyphs', Rock Art Research, vol 19, 2002, pp29-40. 
${ }^{39}$ Hamersley News, 27 June 1974; F.J. Virili, 'Aboriginal sites and rock art of the Dampier Archipelago, Western Australia', in P. J. Ucko (ed), Form in Indigenous Art: Schematisation in the art of Aboriginal Australia and prehistoric Europe, Australian Institute of Aboriginal Studies, Canberra, 1977.

${ }^{40}$ K. Palmer, 'Petroglyphs and associated Aboriginal sites in the northwest of Western Australia', Archaeology and Physical Anthropology in Oceanea, vol 10, 1975, pp152-60.

${ }^{41}$ David Ritter, 'Trashing Heritage: Dilemmas of rights and powers in the operation of Western Australia's Aboriginal Heritage Legislation', in C. Choo and S. Hollbach (eds), History and Native Title: Studies in Western Australian History, no 23, 2003, pp195-208.

${ }^{42}$ Bird and Hallam, op cit.

${ }^{43}$ ibid.

${ }^{44}$ See for example Robin Chapple, 'Environmental protection Authority Legal Action', Press Release, 2 September 1994.

${ }^{45}$ West Australian, 'Rock art site enrages Greens', 25 April 2002 and 'WA Landmarks on endangered list', 23 August 2002.

46 'Burrup claimants hit industry plans', West Australian, 1 June 2002; Australian, 10 June 2002.

${ }^{47}$ Colin Barnett, MLA, Speech to the WA Parliament, 9 March 2003; National Trust, 7 April 2003, 'Dampier Rock Art Precinct Community Forum' (Online), transcript, http://www.burrup.org.au/Resources and Links.html accessed 14 August 2009.

${ }^{48}$ Author, pers comm.

${ }^{49}$ Ibid.

${ }^{50}$ ABC, 4 September 2006 (Online), 'Campbell to consider heritage request for Burrup Peninsula', http://www.abc.net.au/news/newsitems/200609/s1732444.htm accessed 14 August 2009.

${ }^{51}$ See for example Telegraph, 19 May 2006; South China Morning Post, 22 May 2006; Christian Science Monitor, 1 June 2006; Time Asia Magazine, 14 August 2006; Middle East Times, 5 September 2006; Gulf Times, 6 September 2006; International Herald Tribune, 17 September 2006; Forbes Asia, 2 October 2006; Khaleex Times, United Arab Emirates, 2 October 2006; La Republica, 6 February 2007; O Globo, Rio de Janiero, 7 February 2007; Reuters UK, 26 September 2007; Dampier Rock Art and Associated Media Files (Online), Available: http:/ / www.dampierrockart.net/Media/ accessed 14 August 2008. See also Friends of Australian Rock Art (Online), Available: http:// standupfortheburrup.com/FARA (Accessed 14 August 2009) and GetUp (Online), Available:

http: / / www.getup.org.au / campaign/SaveOurHeritage\&id=19 accessed 14 August 2009.

${ }^{52}$ Hon Michelle Roberts, WA Votes and Proceedings, 27 February 2006.

${ }^{53}$ WA Business News, 'Work starts on Woodside gas plant on Burrup Peninsula', 8 January 2007.

${ }^{54}$ Hon Malcolm Turnbull, 3 July 2007, ‘Dampier Archipelago Joins National Heritage List', Media Release, (Online). Available: http:/ / www.burrup.org.au/20070703Release.pdf accessed 14 August 2009; also Australian Heritage Council, nd, National Heritage assessment of the Dampier Rock Art Precinct, (Online), Australian Heritage Database, 
Commonwealth Department of Environment and Heritage, Available: http: / / www.environment.gov.au/heritage / places / national / dampierarchipelago/index.html accessed 14 August 2009.

${ }^{55}$ WA Department of Indigenous Affairs, nd (Online), No longer available: http:/ / www.dia.wa.gov.au/Heritage--Culture/Burrup-Peninsula/ accessed March 2008; West Australian, 'Department damned in indigenous affairs study', 21 November 2007.

${ }^{56}$ Woodside Petroleum Ltd, Media Release, 8 September 2008. See also Woodside, nd, Cultural Heritage Online. Available: http: / / www.woodside.com.au/Our+Business / Projects/Pluto/Sustainabil ity / Cultural+Heritage+Management.htm accessed 14 August 2009.

57 Andrea Witcomb and Kate Gregory, From the Barracks to the Burrup: the National Trust in Western Australia, UNSW Press, Sydney, 2010, p313. 